\title{
Pânico de Palco: Modernismo, Antiteatralidade e Drama
}

\section{A Invenção da Teatralidade}

Stage Fright ${ }^{2}$ (1950) de Alfred Hitchcock é o mistério de um assassinato ambientado no submundo ${ }^{3}$ do teatro. Marlene Dietrich interpreta uma diva cujo luto pelo marido assassinado é tão obviamente teatral que ela se torna imediatamente a suspeita número um do filme. Ela é seguida por uma jovem estudante de artes dramáticas, que prepara uma armadilha para revelar sua culpa. Esperando avidamente pela exposição da diva, a audiência caminha em direção a outro tipo de armadilha, atraídos pelo inteligente contraste entre a atriz imoral, em quem não podemos confiar, pois a atuação se tornou sua segunda natureza, e a novata, em quem podemos confiar por sua inexperiência de palco. O assassino, porém, não é a diva, mas um psicopata que já havia matado antes. Observa-se que o pânico de palco ${ }^{4}$ a que o filme de Hitchcock se refere não é o medo do ator diante da plateia, mas o medo do ator por parte da plateia. ${ }^{5}$

Tal medo ou suspeita, que é evocado por Hitchcock a fim de apresentá-lo à nossa apreciação crítica, é parte de um aparentemente inerradicável e moralizante antiteatralismo, o qual Jonas Barish chamou de "preconceito antiteatral.' Tal preconceito é diverso em seus fundamentos filosóficos, religiosos e morais, se não em suas conclusões, pois

1 Puchner é crítico literário e filósofo. Atualmente é professor na Harvard University.

2 Lançado no Brasil como "Pavor nos Bastidores".

3 Nota do Tradutor: o termo original demimonde refere-se a um submundo específico, precisamente a determinado grupo de mulheres marginalizadas pela sociedade por conta de comportamento promíscuo e muitas vezes envolvendo homens ricos. Uma posição intermediária entre a indiscrição e a prostituição. Também pode-se considerá-lo como sendo um grupo de pessoas cuja respeitabilidade seja dúbia.

4 "Pânico de palco" seria a tradução ao pé da letra do título do filme.

5 Uma mídia mais nova, o filme, reflete aqui uma ansiedade que é própria de uma mídia mais antiga, o teatro. 
permanece retomando um número limitado de obsessões: a imoralidade da exposição pública, de excitar a plateia, e, de modo mais importante, daqueles que praticam profissionalmente a arte da dissimulação. E assim, nós, amantes do teatro, podemos ficar tentados a considerar todas as formas de antiteatralismo como sintomas de um preconceito do qual a cultura precisa ser curada para que o teatro possa progredir. O impulso para proteger o teatro de todos os inimigos antiteatrais tem seus polêmicos méritos, e a eficácia da isca de Hitchcock demonstra a necessidade contínua de tal proteção. Mas ao mesmo tempo, a postura defensiva que é resultado de tal protecionismo também tem seu preço: a tentativa de desfazer ou exorcizar o antiteatralismo obscurece o fato de que a suspeita pelo teatro desempenha um papel constitutivo no período do modernismo, especialmente no teatro e no drama modernistas. Ao contrário de simplesmente desconsiderar a crítica modernista ao teatro como sendo preconceito infundado, cegueira ou ideologia, devemos, porém, perguntar o porquê de ser uma tradição substancial dentro do modernismo achar-se necessário definir a si mesmo em contrariedade com o teatro.

A melhor maneira de caracterizar esta dinâmica constitutiva antiteatral dentro do modernismo é como sendo uma forma de resistência. Não é necessário recorrer a Freud para compreender o quanto o ato de resistência acaba determinado por aquilo contra o que se resiste. A negação e a rejeição inerentes ao termo antiteatralismo não são, portanto, para serem compreendidos como a destruição do teatro, mas como sendo um processo que é dependente daquilo que nega e em relação ao qual, portanto, permanece calibrado. Mesmo as formas mais duras de antiteatralismo modernista se alimentam do teatro e o mantém ao alcance da mão. A resistência registrada no prefixo anti, por conseguinte, não descreve um local fora do horizonte do teatro, mas uma variedade de posturas através das quais o teatro é mantido ao alcance da mão e, no processo de resistência, absolutamente transformado.

Ao analisar um impulso antiteatral dentro do período do modernismo, não desejo aparecer com mais uma teoria monolítica do modernismo. Conforme Richard Scheppard argumentou recentemente, tentativas como esta falharam desde que o termo modernismo foi utilizado pela primeira vez. Ao mesmo tempo, não me contento em anunciar uma pluralidade indiferenciada de modernismos, um posicionamento que não trata de discutir sobre o que seja o modernismo, mas apenas uma recusa a tal discussão. Navegando entre uma teoria monolítica do modernismo e uma feliz pluralidade de modernismos, defendo que existe uma tradição dentro do modernismo que 
pode ser descrita em termos de suas várias formas de resistência ao teatro, mas prontamente reconheci que há modernismos que não caem na categoria de antiteatralismo. Na verdade, defendo que o antiteatralismo modernista encontra sua contraparte em uma segunda tradição, que eu chamo de (pro)teatralismo. A diferença entre antiteatralismo e (pro)teatralismo não é tanto uma dicotomia estável, mas sim uma ferramenta para se analisar uma variedade de posições e fenômenos que virão a ser variadamente entrelaçadas e interligadas.

A fim de compreender as características da resistência ao teatro dentro do período do modernismo, pode-se recorrer àqueles teóricos que explicitamente definem os valores do modernismo através de um ataque ao teatro: Friedrich Nietzsche, Walter Benjamin e Michael Fried. Em 1888, Nietzsche afirmou que o teatro era incapaz de alcançar coerência orgânica e deveria, portanto, ser impedido de exercer sua deplorável influência sobre as outras artes: "Teatrocracia [Theatokratie] -, a loucura de acreditar na primazia do teatro, no direito do teatro comandar as artes, de se comandar a arte." (NIETZSCHE 1991) Nietzsche, aqui, toma o teatro como uma força que impõe seu "comando" sobre as outras artes, levando a uma "teatrocracia", uma forma de governo teatral. Segundo Nietzsche, esta teatrocracia é particularmente evidente em Wagner que sujeita qualquer arte, até mesmo a música, à primazia da representação teatral e, em particular, dos atores; o resultado é uma música que adquiriu atributos do teatro e da interpretação, o que Nietzsche chamou de maneira polêmica de música cênica ou gestual. Se for surpreendente encontrar o autor de The Birth of Tragedy (1871) condenando abertamente o teatro com tanta veemência, pode ser bom lembrarmos que a análise de Nietzsche da tragédia grega continha a impossível projeção de um teatro sem script, sem uma plateia, e, de modo mais importante, sem atores individuais ou individualizados. Podemos começar a reconhecer aqui que o uso derrogatório de Nietzsche do termo teatro é uma objeção específica de Nietzsche contra atores e seus gestos.

A posição antiteatral de Nietzsche é ecoada, algumas vezes ipsis litteris, por Michael Fried, que igualmente considera que o teatro, ou a teatralidade, seja simplesmente o inimigo da arte. (FRIED, 1998) O entendimento repulsivo do teatro de Fried, assim como o de Nietzsche, se preocupa primariamente com a influência do teatro sobre outras artes, em seu caso não sobre a música, mas sobre pintura e escultura. E novamente encontramos uma crítica particular ao ator motivando essa postura antiteatral. Nas formulações frequentemente metafóricas de Fried, pinturas ou esculturas 
"teatrais" são descritas como se fossem atores; tais esculturas estão cientes da audiência e dessa forma perdem sua unidade e integridade autossuficientes, no processo em que começam a lembrar fúteis atores humanos se insinuando para a plateia. De fato, Fried atribui a tais obras teatrais uma qualidade "antropomórfica" que conduz a uma espécie de "naturalismo" personificado. (FRIED, 1998, p.19) A suspeita do ator vivo que fala através da linguagem figurada de Fried se torna aparente quando ele diz que a única forma de arte segura de tais efeitos antropomórficos deploráveis é o filme. Em contraste com o teatro infinitamente personalizante, o filme não apenas retira os atores da presença da plateia, como também os corta em pedaços através de close-ups e montagem. (FRIED, 1998, p.171)

Foi Walter Benjamin quem transformou esta diferença de postura entre o teatro e o cinema em relação aos atores em uma teoria geral de arte modernista. Para ele, o teatro, mais do que qualquer outra forma de arte, retira do ritual seu investimento na intensa presença viva que conecta o ator ao público. Esta presença vivencial, e por isso única, significa que o teatro está empossado de maneira singular do que Benjamin chama de "aura", que transforma esta personagem viva em um valor absoluto. Para Benjamin, este uso do termo aura é ele mesmo uma retroprojeção, pois seu ensaio está mais preocupado com a maneira pela qual o filme foge desta qualidade aurática por transformar o ator humano intérprete em nada mais do que um material dentre outros, um material que é infinitamente manipulado, fragmentado, e despersonificado por um aparato que agora media a relação entre o ator e o público. Posto que "A Obra de Arte na Época de sua Reprodutibilidade Técnica" deriva todos os seus termos "negativos" do teatro, ele deve ser compreendido menos como um tratado pró-filme e mais como um tratado antiteatral em que o ator vivo se torna um obstáculo a uma arte verdadeiramente modernista.

A natureza extrema e polêmica dessas declarações podem ser explicadas em parte por seus respectivos contextos: a ruptura de Nietzsche com Wagner (aproximadamente entre 1876 e 1878); os ataques de Fried ao minimalismo de 1967; e a tentativa de Benjamin de entrar em termos com as implicações do filme em 1934. Considerar esses contextos também significa reconhecer que os ataques desses teóricos ao teatro não indicam uma simples rejeição a ele. Nietzsche, por exemplo, procurou introduzir uma forma de teatralidade em sua filosofia; Benjamin foi atraído pelo drama alegórico do alemão Trauerspiel; e a polêmica de Fried não se dirige contra o teatro per se, mas 
contra certos tipos de pintura e escultura; ele até mesmo admira Brecht por voltar o teatro contra si mesmo. Mesmo assim, as articulações antiteatrais desses diferentes teóricos apontam para além dos contextos polêmicos e em direção a uma maior, e também mais difusa, tendência operativa antiteatral dentro do período do modernismo.

Traços de tais formas teóricas de antiteatralismo podem ser encontradas, por exemplo, no trabalho de Theodor W. Adorno. Adorno herda de Nietzsche uma crítica à música teatral e gestual, que dirige, então, não apenas contra Wagner, mas também contra Stravinsky, a quem acusa de deixar o balé influenciar sua música, fazendo com que regrida para o nível de "brincadeiras gestuais" de crianças. (ADORNO, 1978, p.150) Para toda a distinta teoria de Adorno sobre a mimese - e sua defesa da mimese contra seus detratores formalistas - o que existe por trás de sua crítica a Wagner e Stravinsky é a crítica a uma forma primitiva de mimese que lembra Adorno das performances do tipo "macacos que parecem humanos se apresentam nos zoológicos". (ADORNO, 1970, p.181) Essa mimese primata ou picaresca não deve ser simplesmente reprimida; ela precisa ser internalizada e "lembrada alegremente [tröstlich]" para o propósito expresso de evitar o tipo de regressão de que Stravinsky é culpado. Somente quando houver negado com sucesso tal mimese primata, a arte poderá integrar a mimese de uma forma propriamente modernista.

Contemplando essas formulações esparsas, começa-se a suspeitar que os macacos e palhaços que simbolizam uma forma atávica de mimese são figuras para o ator de baixa qualidade. Quando lemos os ensaios de Adorno sobre Brecht e Beckett sob esta luz, fica claro que para ele o sucesso do modernismo no teatro depende da habilidade do teatro para resistir ao pessoal, o individual, o humano, e o mimético - os quais estão todos amarrados ao atores que encenam. Na verdade, Adorno defende que a dependência do teatro na individuação é um "fardo insustentável" do qual mesmo Brecht sofreu, mas contra o qual ele se rebelou com sucesso. Beckett, entretanto, é o dramaturgo que lidou com este fardo mais convincentemente, ao atacar implacavelmente a presença de "realidade e pessoas" no teatro e por transformar essas pessoas em "máscaras vazias". (ADORNO, 1974) Atores humanos vivos são permitidos apenas quando estão absolutamente despersonificados. O que é impressionante sobre Adorno, Fried e Benjamin é que seus vários antiteatralismos são baseados não em ataques externos ao teatro, mas ao próprio teatro modernista. $\mathrm{O}$ fato de Brecht e Beckett permanecerem entrando nessas polêmicas não como exemplo do que há de 
errado com o teatro, mas como soluções para essas objeções dos teóricos ao teatro pode servir como uma primeira indicação do papel formador e produtivo desempenhado pelo antiteatralismo para o drama e o teatro modernos.

O que está por trás dos ataques antiteatralistas contra os atores não é a suspeita mais tradicional, moralizante, de que atrizes são prostitutas (ou, no caso de Marlene Dietrich, inclinadas a assassinarem seus maridos), nem os outros aparentemente inerradicáveis topoi do tradicional preconceito antiteatral (que eles subvertem a ordem social; que eles ensinam trapaças e mentiras), mas um conjunto de valores especificamente modernistas que é um dos propósitos do meu estudo detalhar. Não que as formas modernistas de antiteatralismo não bebam do preconceito mais antigo, moralizante. Mas não importa a que ponto os críticos modernistas do teatro ainda estejam imbuídos deste "preconceito", eles o integram em um novo e especificamente moderno conjunto de questões. O que eles tendem a objetar é uma forma particular de mimese atuante no teatro, uma mimese causada pela posição desconfortável do teatro entre as artes performáticas e miméticas. Enquanto uma arte performática como música ou balé, o teatro depende da habilidade artística de intérpretes humanos vivos no palco. Enquanto uma arte mimética como pintura ou cinema, porém, ele precisa usar esses intérpretes humanos como material significante a serviço do projeto mimético. Uma vez que a natureza da mimese esteja submetida ao escrutínio e a ataques, como está no modernismo, essa dupla filiação do teatro se torna um problema porque, diferente da pintura ou do cinema, o teatro permanece ligado aos intérpretes humanos não importa o quão alienada possa ser sua atuação. O teatro acaba ficando, assim, fundamentalmente em conflito com uma crítica, ou complicação, mais amplamente divulgada da mimese porque essa crítica requer que o material usado no trabalho artístico seja capaz de abstração e distanciamento. Diretores podem tentar distanciar ou despersonificar esses humanos intérpretes, treinando e controlando seus movimentos e gestuais, e a análise de Joseph Roach da "ciência da atuação" traça a história dessas tentativas. (ROACH, 1993) Mas a personificação do ator permanece mesmo assim travada fundamentalmente em um tipo de mimese não mediado que impede a obra de arte de atingir estruturas internas complexas, reflexividade distanciada e constituição formal.

A problemática presença do ator humano no palco tem sido obscurecida por muitos ramos da semiótica do teatro, que tende a assumir que assim que um corpo 
humano é enquadrado pelo palco, ele automaticamente se torna um signo, como se por definição. Entretanto, declarar simplesmente que os atores sejam signos "homomateriais" - os humanos (ao contrário da tinta) significando outro humano - tende a apagar as tensões e problemas particulares causado pela presença continuada de atores humanos na produção desses signos. Um problema premente é que nenhum controle total sobre a emissão desses signos jamais será possível. Do ponto de vista da recepção, esse fato gera uma crise dos signos teatrais: nunca saberemos exatamente quais gestuais e movimentos são parte do trabalho artístico e quais deles são resultados de acidentes no palco. Enquanto esta incerteza pode não ser um problema para o aparato semiótico formal, ele é um problema para a plateia, que continua a estar diante daquilo que não pode deixar de ver como contingências, acidentes, maneirismos individuais e idiossincrasias. O mesmo problema aparece do lado da produção. Reformadores do teatro tais como Edward Gordon Craig insistem em reter total controle sobre seu material e por conta disso, tentam substituir atores vivos por marionetes, enquanto outros tais como Oskar Schlemmer, Nicolai Foregger e Vsevolod Emilievich Meyerhold tentam transformar o ator humano em uma máquina. Mesmo D. H. Lawrence escreveu que "drama é encenado por criaturas simbólicas formadas a partir da consciência humana: títeres, se preferir: mas não indivíduos humanos. Nosso palco está todo errado, tão apático em sua personalidade." (LAWRENCE, 1989, p.201-2) Esses diversos escritores parecem concordar em uma coisa; a dependência do teatro em seus atores humanos é sua maior desvantagem, e um teatro modernista apenas pode surgir do ataque contra eles. Esta agressão contra o ator, pode-se dizer também que causou o que Elianor Fuchs chama de "morte da personagem": uma vez que a figura do ator esteja sob ataque ele não pode mais prometer personificar o que era anteriormente conhecido como uma personagem. (FUCHS, 1996)

Para se compreender a emergência de uma resistência modernista contra o teatro, é necessário examinar a tradição contra a qual este antiteatralismo reage e, assim sendo, pela qual é moldada: a ascensão, no final do século XIX, de uma celebração sem precedentes do teatro e da teatralidade que se poderia chamar de teatralismo. É difícil não ser afetado pela energia nervosa daqueles reformistas e revolucionários do teatro da virada do século que tomaram para si o trabalho de resgatar o teatro daquilo que eles pensavam como sendo seu acelerado declínio. Se os sintomas desse declínio - a ganância dos gerentes do teatro, a vaidade dos atores que eram estrelas, o trabalho convencional, 
comercial dos dramaturgos, e os gostos vulgares das plateias - podem nos impressionar enquanto topoi familiares na história do teatro, as conclusões que esses utópicos do teatro tiraram delas, não. Sua crítica ao teatro contemporâneo não se encarregava tanto de melhorar o gerenciamento, atores, dramaturgos e plateias quanto de resgatar e promover o teatro, ou a teatralidade, como tal. A retórica tautológica desses reformistas foi capturada em uma frase cunhada por George Fuchs em 1904: "a re-teatralização do teatro". (FUCHS, 1905) Esse slogan foi ecoado pela nova classe de estrelas da direção e por teóricos, que tentavam arrancar o teatro das mãos dos atores e produtores; isso pode ser encontrado, por exemplo, em On the Art of the Theatre (1911) de Edward Gordon Craig, La mis-en-scène du drame Wagnérien (1895), Rejuvenation of the Theatre (1913), e The Theater as Such (1913) de Nicolai Evrainov. (FISCHER-LICHTE, 1997) Tais posições foram subsequentemente tomadas por extremas pela emergente vanguarda: F.T. Marinetti declarou em 1915 que "tudo de qualquer valor é teatral" (MARINETTI, 1968, p.117); os dadaístas fizeram de tudo para arrastar todas as artes para o Cabaret Voltaire; e Antonin Artaud clamou por uma fusão entre a vida e o teatro. O que começamos a verificar aqui é que a polarização entre antiteatralismo e teatralismo corresponde até certo ponto à distinção feita por um certo número de teóricos entre alto modernismo e vanguarda. Podemos, assim, falar de um antiteatralismo modernista e um teatralismo de vanguarda.

Porém, estou menos interessado em manter a velha distinção entre alto modernismo e vanguarda do que em reformulá-la em termos de antiteatralismo e teatralismo. Na verdade, antiteatralismo modernista e teatralismo de vanguarda às vezes chegam a conclusões similares, por exemplo, uma crítica do teatro atual. O desejo de ir além dos espaços circunscritos do teatro deixou alguns dos teatralistas insatisfeitos não apenas com o palco e seus atores miméticos, mas com quase todas as formas existentes de teatro, um atributo visível, por exemplo, na exigência de Marinetti de uma "teatralitá senza teatro" (teatralidade sem teatro) (1968). As formas mais radicais de teatralismo, assim, chegam a algumas das mesmas conclusões àquelas alcançadas pelo antiteatralismo, e às vezes uma crítica particular ao teatro parece pertencer a ambos os campos (um exemplo é Craig, outro, talvez, Nietzsche). Isso não significa, no entanto, que uma divisão não possa ser traçada entre os ataques ao teatro motivados por uma celebração do valor da teatralidade e aqueles motivados por uma resistência a ela. $\mathrm{O}$ que a concordância parcial entre proteatralistas e antiteatra- 
listas demonstra é uma irreversível dissociação do valor da teatralidade a partir das realidades do teatro real. Essa dissociação tem implicações de longo alcance, com a mais importante sendo não que o pró-teatralismo possa se voltar contra o teatro real, mas, inversamente, que o antiteatralismo possa retornar ao teatro. Se existe, conforme Marinetti sugere, uma "teatralidade sem teatro", então também existe um "teatro sem teatralidade". O drama e o teatro modernistas podem ser considerados exatamente isso, um teatro em conflito com o valor da teatralidade. Uma análise do teatro antiteatral demanda não uma história descritiva do teatro, mas uma história do valor do teatro ou da teatralidade, o que poderia ser chamado, emprestando o termo de Nietzsche, uma "genealogia" do teatro.

Não é nada surpreendente que os discursos contemporâneos sobre o teatro não sejam simpáticos à resistência modernista contra o teatro. Inúmeros artigos na área do teatro e estudos performáticos começam com um ataque aos supostos "inimigos" do teatro, tais como Michael Fried. Esses ataques têm valor limitado, nem tanto por não fazerem justiça à teoria de Fried, mas porque eles perpetuam a relutância ou incapacidade por parte dos estudos do teatro de tomar o antiteatralismo por qualquer coisa que não seja uma força do mal. Ao mesmo tempo, a maioria das práticas teóricas que ajudaram a institucionalizar o modernismo literário - Nova Crítica, formalismo, estruturalismo e desconstrucionismo - tenderam a negligenciar a categoria do teatro. Yvor Winters e Helen Vendler, por exemplo, reduziram abertamente as peças de Yeats a literatura poética que nada tem a ver com o teatro. (VENDLER, 1963; WINTERS, 1960) Jacques Derrida está empenhado demais em incluir o teatro sob uma écriture geral para reconhecer no teatro textual de Mallarmé uma resistência ao teatro. (DERRIDA, 1972) Mesmo semioticistas explicitamente devotados a analisar a pluralidade de sistemas de signos no teatro, tais como Patrice Pavis, rotineiramente se apoiam na noção de "texto performático," enquanto outros, tais como Anne Ubersfeld, usam o ato de ler para descrever a atividade de se assistir uma peça, como se eles simplesmente não fossem capazes de surgir com uma teoria de emissão e recepção de signos que não fosse no mínimo modeladas metaforicamente na escrita. O problema com tais leituras não é, como acadêmicos da área de estudos do teatro certas vezes argumentam, que eles falhem em celebrar escritores tais como Yeats ou Mallarmé como gênios negligenciados do teatro. Pelo contrário, o completo apagamento da categoria do teatro os torna incapazes de analisar a resistência desses escritores ao teatro, que é, por sua vez, a carac- 
terística central de sua obra. Poderia-se dizer, então, que justamente como o estudo contemporâneo do teatro tende a continuar o teatralismo de vanguarda em virtude de sua dedicação amplamente acrítica ao valor do teatro, o estudo do modernismo literário tende a perpetuar o antiteatralismo modernista através de um apagamento acrítico da categoria do teatro. Neste livro, tento relacionar criticamente estas duas tradições entre si, não com a pretensão de me colocar inteiramente de fora dessa história do valor, mas com a esperança de que uma reflexão sobre essa história possa conduzir à genealogia do valor de teatralidade que o teatro modernista demanda.

A fim de se compreender o teatralismo triunfante da vanguarda e, portanto, a resistência modernista a ela, é necessário não apenas olhar adiante, em direção aos estudos contemporâneos de teatro, mas também olhar para trás, para a figura à qual os partidários do teatro continuam a se referir de uma forma ou de outra, e de quem derivam seus principais slogans, que é Richard Wagner. É por esta razão que meu estudo começa atribuindo a Wagner, que também foi a primeira estrela moderna da direção, a "invenção" do que subsequentemente se tornou o teatralismo de vanguarda. Neste sentido, foi graças a Wagner que a teatralidade foi acusada por todo o fervor reformista, revolucionário e utópico que caracterizam seus próprios manifestos ou escritos do tipo manifesto e aqueles da vanguarda histórica. Porém, ao invés de imaginar alguma forma de teatralidade abstrata, teórica, Wagner insistiu que essa noção de teatralidade deve ser realizada sobre um palco real na forma do Gesamtkunstwerk. A importância de Wagner para o modernismo reside, então, no fato dele haver tomado o teatro como valor absoluto, e ao mesmo tempo, aspirou realizar seu valor no teatro. É precisamente porque Wagner transformou o teatro em um valor que ele foi celebrado pela vanguarda, e pela mesma razão, ele se tornou o objeto dos ataques modernistas antiteatrais mais polêmicos. (HUYSSEN, 1986, p.42) Isso pode ser chamado de efeito Wagner: forçar as artes a tomar uma postura definida em direção ao teatro teatralizado. Destaca-se aqui pois a emergência de uma ambivalência modernista sobre o teatro nos escritos dos críticos de Wagner, para quem ele, quase como uma diva do palco, continua a simbolizar tudo o que pode ser grandioso e fascinante, mas também perigoso e objetável, sobre o teatro e a teatralidade.

Uma vez que reconheçamos que os valores estéticos centrais dominantes no período do modernismo brotam de uma resistência ao teatro, podemos questionar por que esses valores surgiram, antes de tudo. Quais eram as condições sob as quais uma 
tradição interna ao modernismo começou para adotar precisamente aqueles valores que a colocam em conflito com o teatro? Para responder esta pergunta, é necessário nos voltarmos para as condições históricas e sociais que deram impulso ao alto modernismo. Tornou-se uma crítica clichê observar que muito da arte modernista descolou-se de qualquer engajamento direto com a esfera pública e os modos de representação exigidos para isso, em particular a ideia de que a esfera pública inevitavelmente levaria a uma arte popular, uma arte para as massas. O antiteatralismo modernista pode ser visto como uma reação a esse medo das massas e da esfera pública. Por isso mesmo, o abraço da vanguarda ao teatro e ao teatralismo pode ser tomado como um sinal da maior afinidade da vanguarda com o populismo e as massas, o que Andreas Huyssen chama de "dialética oculta" de vanguarda e cultura de massa.

O teatro sempre foi a forma de arte mais pública, e continuou a depender da colaboração da coletividade mesmo em um tempo em que o modernismo celebrou a figura do artista individual, que se subtrai à esfera pública e às supostas massas indiferenciadas. Interseccionando-se mais diretamente com as duras restrições dos negócios, o teatro depende de um processo de produção colaborativo que inclui gerentes voltados a negócios, atores sonhando com o estrelato, e dramaturgos prontos a agradarem uma audiência em busca de prazer. Esse processo colaborativo era uma maldição pra os modernistas antiteatrais, mas também incomodou os reformadores do palco de maneira geral. A ascensão do chamado teatro de diretor no final do século XIX pode ser vista como uma tentativa de reduzir a colaboração no teatro e concentrar os atos de criação nas mãos de um superdiretor. Esta motivação é particularmente evidente no caso de Craig, cujos polêmicos ataques ao teatro foram feitos a serviço de obter total controle sobre o processo de produção e assim sendo, de eliminar todas as contingências associadas à colaboração.

O processo de produção colaborativa é, porém, apenas um lado do problema; o outro lado é a recepção coletiva de performances teatrais. Para muitos modernistas, a recepção coletiva provou ser ainda mais perturbadora do que produção coletiva e foi por esta razão que começaram a celebrar agressivamente as virtudes da leitura solitária como modelo para se assistir uma peça. Fried deu um nome a essa preferência, compartilhada por muitos modernistas, de ler a assistir e de texto a teatro, chamado absorção. (FRIED, 1980) Fried se incomoda com os atores vivos no palco, mas ele está no mínimo tão perturbado quanto pelas pessoas na plateia, cuja presença rompe com o que havia se tornado condição sine qua non do modernismo: uma intensa concen- 
tração sobre trabalhos que se encaixam no ideal modernista da dificuldade. Tal ideal requer um controle sobre as circunstâncias externas de recepção que é impossível de se implementar no teatro. Um certo número de escritores modernistas desejavam extrair uma conclusão radical da natureza colaborativa e coletiva inerente ao teatro: liderados por Mallarmé, eles se retiraram para seus estúdios e gabinetes particulares, que assim se tornaram os berços do drama modernista.

Tanto os amigos quanto os detratores do teatro sempre suspeitaram que junto com sua produção colaborativa e sua recepção coletiva, vinha uma relação mais direta com as esferas social e pública. Anedotas e histórias sobre insurreições e revoluções causadas por performances teatrais ocupam um lugar de destaque na imaginação dos entusiastas do teatro. $\mathrm{E}$, deveras, a reunião comunitária de um público no teatro tem sido usada como modelo recorrente para o público em geral. Esta afinidade ajuda a explicar por que estudos sociológicos tais como Strukturwandel der Öffentlichkeit (1962) de Habermas considerariam as pessoas reunidas no teatro como sendo uma "base de treinamento" para a formação de uma política pública apropriada. (HABERMAS, 1990, p.88) E o que para Habermas é apenas uma prefiguração torna-se um modelo de organização no Fall of the Public Man (1977) de Richard Sennett, que usa a história do teatro e seu público como, alternativamente, uma instância e uma causa locais, e um correlativo objetivo à natureza mutante da esfera pública nos séculos XVIII, XIX e XX. (SENNET, 1977) O próprio estudo de Sennett continua uma longa tradição de pensamento político que considera que a esfera pública talvez seja uma forma de theatrum mundi. A força dessa tradição fica registrada mais claramente, talvez, por seu maior crítico, Jean-Jacques Rousseau, cujo medo de que o teatro possa corromper a esfera pública presume que os dois sejam homólogos o suficiente para o primeiro ter tal efeito prejudicial sobre o último. (ROUSSEAU, 1967)

A afinidade vista entre o teatro e a esfera pública é um fator chave na formação de um antiteatralismo especificamente modernista. Graças a esta afinidade, o teatro, ou $\mathrm{o}$ ato de teatralizar outras formas de arte como pintura ou escultura, ameaça devolver a arte à esfera pública. $O$ investimento em proteger os receptores do público não significa apenas permitir a eles que apreendam, com a máxima concentração, a complexidade da obra de arte. Tanto a insistência com a complexidade quanto os tipos de receptores demandados por ela são respostas ao medo de que o teatro possa realmente prover um fórum em que a construção de opinião pública possa tomar lugar. A crítica modernista do realismo, da mimese e do literalismo, e sua fixação na absorção 
silente e solitária não são, portanto, valores independentes que por acaso estão em conflito com o que o teatro representa; eles são barreiras erigidas contra a possibilidade do papel público da arte sugerido pelo teatro.

Podemos ver aqui também até que ponto a polarização entre antiteatralismo e pró-teatralismo corresponde àquela entre modernismo e a vanguarda. Enquanto o antiteatralismo modernista atacava o teatro para impedir o engajamento político direto, a vanguarda reconhecia que o teatro era o ponto arquimediano a partir do qual se podia atacar os valores mais centrais do modernismo. A vanguarda não celebrou a teatralidade simplesmente partindo de um amor inocente pelo teatro; ela escolheu a teatralidade - tão bem como tudo relacionado a ela, tal como produção colaborativa, recepção coletiva, distração, e plateias turbulentas - como seu slogan precisamente porque a teatralidade prometia conduzir a arte de volta à esfera pública da qual o modernismo havia se distanciado tão avidamente. Este compromisso do teatro com a esfera pública já é visível na obra de Richard Wagner. Para ele, o teatro de Bayreuth se torna uma arena política ideal epitomando a Alemanha e o Volk alemão. Entretanto, o olhar para o teatro como um lugar político privilegiado não se origina com Wagner. O teatro tem sido a forma de arte escolhida por projetos que procuram fundir estética e política, como é visível, por exemplo, dos argumentos colocados através da Europa em favor do estabelecimento de teatros nacionais. A instrumentalização do teatro para a política também está por trás da diagnose antiteatral de Walter Benjamin de uma "estetização da política" fascista, pois esta estetização é mais drasticamente alcançada nos rituais teatrais fabricados pelo fascismo, dos espetáculos e paradas para massas aos cuidadosamente orquestrados Ralis de Nuremberg. (BENJAMIN, 1977) A crítica antiteatral de Benjamin de arte aurática é, portanto, motivada por sua experiência com os rituais político-teatrais do fascismo.

A tese de Benjamin sobre o fascismo, porém, deve ser ampliada para incluir uma gama maior de fenômenos, pois a conjunção entre estética e política teatral pode ser encontrada também em projetos revolucionários como o dadá de Berlin, assim como o espetáculo de agitprop ${ }^{6}$ de Meyerhold The Storming of the Winter Palace (1920). Ambas são formas extremas do que Raymond Williams chamou de "teatro enquanto fórum político". (WILLIAMS, 1989) Sem criar um falso paralelismo entre a política teatral do fascismo e aquelas da jovem União Soviética, que poderia, por exemplo, 
apagar a diferença entra uma plateia silenciosa massiva oprimida por um espetáculo e uma massa politizada que participa da recriação de uma ação coletiva revolucionária, ainda assim é central reconhecer que ambos basearam suas esperanças na criação de um público político no teatro. De fato, a ascensão no início do século XX do que hoje é conhecido como política de massa, que foi acolhida por alguns teatralistas, como Marinetti, enquanto realização de uma nova teatralidade, deu uma nova e notória dimensão política à desconfiança das massas do final do século XIX. Ainda que esta associação entre o público em massa e o teatro possa parecer basear-se em um entendimento limitado tanto do teatro quanto da esfera pública - e indicarei alguns caminhos alternativos para se pensar sobre esta relação - é importante reconhecer que essa associação é uma das forças motrizes por trás do teatralismo (de vanguarda) e do antiteatralismo (modernista), de modo semelhante.

Mas onde é que esta consideração deixa o teatro modernista? Pegos, digamos assim, entre a cruz da crítica modernista do teatro e a espada do teatralismo de vanguarda, como um drama e um teatro modernistas poderiam emergir - ao invés de espetáculos de vanguarda - dessa batalha pela teatralidade? O próprio termo teatro modernista não nos deveria impressionar como um oximoro? Defendo que o drama e o teatro modernos, talvez surpreendentemente, não sofreram tanto de seus inimigos modernistas e entusiastas de vanguarda; pelo contrário, eles internalizaram tanto a crítica quanto o entusiasmo pelo propósito de uma reforma de profundo alcance da forma dramática e da representação teatral. O drama, como o filme de Hitchcock, tem sempre registrado e respondido aos argumentos de seus detratores. As Bacantes de Eurípedes, por exemplo, personifica o perigoso ator no Dioniso Asiático e o medo de palco antiteatral no moralista Penteu. O drama moderno continua a registrar o antiteatralismo - em nenhum lugar mais obsessivamente do que na obra de Luigi Pirandello - mas se permite também ser moldado pelo antiteatralismo. A desconfiança de Brecht com o teatro, a invectiva de Yeats contra os atores, o nervosismo de Stein na presença de atores reais, e a rejeição de Mallarmé pelo teatro são variedades de uma resistência ao teatro que são estruturais e fundamentalmente formativas, moldando o uso do texto dramático, dos dramatis personae, e de atores por esses escritores. Não mais interessados em banir atores ou fechar teatros, o antiteatralismo modernista não permanece externo ao teatro, mas pelo contrário, se torna uma força produtiva responsável pelas realizações mais gloriosas do teatro. 


\section{O Drama Modernista de Gabinete}

A parte II constrói e analisa um grupo de textos marcados pela resistência modernista ao teatro, que chamo de drama modernista de gabinete. Previsivelmente, o drama de gabinete foi desdenhado pelos promotores do teatralismo como Wagner, que o chamaram de aberração "ultrajante" (WAGNER, 1971-73, Vol.3, p.132), por sua recusa teimosa a reconhecer o valor da teatralidade total. Mas Wagner estava longe de ser o único a sentir desprezo pelo gênero. $O$ drama de gabinete nem interessa a estudos do teatro (e performance) hostis aos textos literários, nem aos estudos literários sem interesse no teatral (mesmo quando o valor do teatro está sendo questionado). O resultado dessa dupla negação é que o drama de gabinete é um dos gêneros menos analisados e menos compreendidos. E ainda, conforme minha argumentação, é apenas através do drama de gabinete que podemos começar a entender como o drama moderno se relaciona com o teatro.

O único teórico a reconhecer o valor do drama de gabinete foi Georg Lukács, que o viu como sintoma de um dilema central no drama moderno em geral. Hoje visto primariamente como crítico da novela, Lukács na verdade começou como estudioso do drama, e seu primeiro estudo crítico descreve o teatro do século XIX como padecente de uma crescente evasão de público, processo que no final levou a uma cisão entre drama e teatro Lukács vê esta evasão de público como resultado da falha do teatro em expressar a condição moderna. "A vida não é mais dramática". (LUKÀCS, 1981), ele exclama, concluindo que o drama não é mais capaz de falar a um público de massa. O sintoma deste dilema, se não sua solução, é a emergência do drama de gabinete, ou Buchdrama, que por sua vez desistiu completamente do público. Sem assinar embaixo do diagnóstico pessimista de Lukács, e suas suposições subjacentes sobre a relação entre a vida e a forma dramática, atenho-me à observação de que o drama de gabinete expressa algo crítico sobre a condição do drama moderno. Mas onde Lukács toma o drama de gabinete para marcar o fracasso do drama moderno, vejo isso como a mais clara expressão de uma resistência modernista ao teatro.

Uma razão para a relativa rejeição ao drama de gabinete é a natureza particularmente instável dessa categoria. O drama de gabinete parece depender dos caprichos dos gerentes do teatro e do orgulho ferido dos dramaturgos, desde Sêneca até Milton e Byron, que "oficialmente" se recusaram a escrever para o palco tão logo se sentiram rejeitados por ele. Mas o que acontece quando a moda (e a censura) teatral 
muda e esses dramas de gabinete acabam sendo encenados depois de tudo, contra a vontade declarada dos desapontados dramaturgos? Hoje, nosso entendimento da relação entre texto e teatro mudou tanto que quase todo tipo de texto pode ser e tem sido trazido para o teatro. Além disso, enquanto muitos pretendem que os dramas de gabinete sejam colocados no palco retroativamente, a tragédia grega, no mínimo a partir de Aristóteles, tem sido considerada há muito tempo como um ramo da literatura e consequentemente integrado ao cânone pedagógico. Isso significa que ela é lida, estudada, circulada, copiada, transcrita, traduzida e finalmente impressa como literatura ao invés de scripts feitos para serem interpretados. Uma história similar de recepção tem ocorrido com Shakespeare. (SCOLNICOV \& HOLLAND, 1991) A observação de Coleridge de que Shakespeare tinha seu "próprio lugar no coração e no gabinete" pode ser tomado como um sentimento representativo de toda uma tradição de admiradores antiteatrais de Shakespeare. (RICHARDSON, 1988; HELLER, 1990; SIMPSON, 1998) A consequência desta convicção foi que qualquer drama pronto para competir com Shakespeare teria que aspirar à condição do closet de Coleridge.

A intencionalidade e a história da recepção são, porém, apenas os marcos externos do que eu tomo por ser intrínseco ao drama de gabinete enquanto gênero: sua resistência ao teatro. Esta resistência se manifesta ao longo da história do drama de gabinete, especialmente em sua origem na tradição greco-latina, nomeadamente, nos diálogos de Platão. (Pode-se considerar o amplamente dialógico livro de Jó como o primeiro drama de gabinete na tradição judaico-cristã; ele também serviu de modelo estrutural para o Fausto de Goethe, que foi o drama de gabinete mais influente do século XIX). Chamar os diálogos de Platão de drama de gabinete é em si uma atribuição retroativa, pois não são nem tragédias e nem comédias, e por conta disso não teriam sido reconhecidos pelos gregos como drama, absolutamente, a despeito de sua mimese do movimento, da interação e do gesto. Aristóteles, porém, tinha apreço pelo que certas vezes, e desajeitadamente, chamou de "forma literária" dos diálogos socráticos, e ele sagazmente os relacionou às comédias em prosa de Xenarco e Sófron. (ARISTOTLE, 1995, 1447b) A conexão que ele desenha dessa forma é uma crítica subliminar a seu professor, que não queria ser lembrado como autor de esquetes cômicos, quanto mais ser categorizado como criador de peças de mimese em prosa. O fato de Platão, o fundador do antiteatralismo, ter se convertido à forma dramática certamente complica sua posição antiteatral, mas isso sinaliza uma tensão que marca 
o drama de gabinete ao longo de sua história, por ele permanecer vinculado ao teatro ao qual ele luta para combater.

A resistência ao teatro nos diálogos de Platão se manifesta em duas tradições do drama de gabinete, das quais uma podemos chamar de drama de gabinete comedido, e a outra de drama de gabinete exuberante. O drama de gabinete comedido, indo de Platão a Hofmannsthal, passando por Milton e Swiburne, consiste de falas e monólogos filosóficos ou poéticos, um teatro caracterizado pela retirada da ação cênica e pela resistência a ela. Na verdade, Hofmannsthal traçou uma conexão explícita entre seu drama de gabinete lírico Der Tod des Tizian e Platão, observando que talvez "não se deveria chamá-la de peça para o teatro [Theaterstück], mas um diálogo à maneira de Platão de Atenas". (HOFMMANSTHAL, 1982, p.377) O drama de gabinete exuberante também resiste ao palco, mas o faz através de um excesso de ação teatral. $O$ Fausto II de Goethe, La Tentation de Saint-Antoine de Flaubert, e The Enemy of the Stars de Pound são exemplos de tal teatralidade flutuante e frequentemente alegórica, cujas constantes mudanças de cenas, enormes elencos de personagens, aparições e desaparecimentos repentinos, e estratégica mistura de alucinação e realidade propositalmente excedem os imites da representação teatral.

Enfatizo a resistência ao teatro do drama de gabinete porque o drama de gabinete modernista a leva ao extremo. E como qualquer forma de resistência, o drama de gabinete se refere àquilo que resiste e constantemente se mantém em contato com ele. Quer tenda para a tradição comedida, quer para a exuberante, o drama de gabinete modernista nunca abandona o teatro e transforma sistematicamente seus espaços, atores e objetos. Por essa razão, seria errado considerar o drama de gabinete uma negação ao teatro. Pelo contrário, devemos perguntar o que o drama de gabinete quer do teatro, como se nutre de sua crítica ao teatro, e como esta necessária relação conduz o drama de gabinete, não a acabar com o teatro, mas a transformá-lo.

Tais transformações assumem formas particularmente convincentes e de grande alcance nos dramas de gabinete de Mallarmé, Joyce e Stein, os quais, portanto, estão no centro de minha análise. Nas mãos desses escritores, as dramatis personae projetadas são transformadas em montagens isoladas de gestos e poses que são infundidas com significação simbolista (Mallarmé), ou usados para a construção de uma montagem teatral (Stein), ou feita para oscilar entre alucinação e a realidade do palco (Joyce). Tornou-se comum atribuir à cultura teatral da virada do século um retorno do 
corpo, que Harold Segel chamou de "o corpo ascendente", e a ascensão desse corpo é frequentemente tomada como uma reação contra não apenas o texto dramático, mas também uma "crise de linguagem" mais amplamente distribuída, como Erika Fischer-Lichte argumentou. (SEGEL, 1998; FISCHER-LICHTE, 1997, p. 63) O drama de gabinete pode ser visto como a parte inferior desta polarização: aqui está a linguagem, na forma de um drama de gabinete, que corresponde e até mesmo "soluciona" o que então poderia ser visto como a crise do ator. O que é mais notável, talvez, do que esta reversão é o fato de que teatralismo e antiteatralismo se encontram aqui uma vez mais em seu ataque compartilhado sobre a natureza individual e humana do ator. Enquanto Craig demanda que o ator seja substituído por um marionete, muitos escritores de dramas líricos ou escreveram peças para marionetes, como fez Maeterlinck, ou imaginaram ter suas peças encenadas por marionetes, como fez Hofmannsthal. No caso de Mallarmé, Joyce e Stein, porém, nenhuma referência a uma real substituição do ator humano é necessária ser trazida para uma completa despersonificação da figura humana, por eles empregarem modos de representação textual que explicitamente impedem qualquer ato de personificação.

Dado que a resistência ao teatro do drama de gabinete é uma instância particular da resistência modernista à esfera pública, é tentador dirigir contra ele o tipo de crítica que Lukács e Bürger colocaram contra o alto modernismo mais geralmente. A partir de tal perspectiva, o gênero do drama de gabinete pareceria ser indicativo de um afastamento deplorável da responsabilidade artística e uma adesão narcisista a um tipo de variante de l'art pour l'art; de fato, os primeiros dramas de gabinete modernistas, de Mallarmé a Hofmannsthal, são inegavelmente parte do esteticismo. E desde que o gabinete é o que se define por sua separação da esfera pública da plateia, é tentador considerar isso como a própria imagem da retirada para o espaço privado. Entretanto, esta visão é pega na equalização indiferenciada do teatro, da esfera pública, e da política sobre a qual o teatralismo político de Wagner, Marinetti e Meyerhold é baseada. Tão logo suspendamos este pressuposto, podemos ver que os dramas de gabinete de Mallarmé, Stein e Joyce se retiram do público não tanto para celebrar narcisisticamente sua própria autonomia, mas sim para resistir a formas particulares de normatividade que eles associam com a representação teatral.

O aspectos mais visíveis da normatividade do teatro são a maior vigilância do censor, o (percebido) conservacionismo dos gerentes de teatro e do gosto do público, 
e formas de censura internalizadas. O drama tem se inclinado a funcionar como um gênero privilegiado para reflexão moral e instrução em virtude de representar as ações dos participantes de um mundo socializado. Apesar deste papel moral ter levado a formas de oposição teóricas ao status quo, mais fundamentalmente, ele tem levado a um maior policiamento da representação teatral. $O$ fato de que o teatro está preso à normatividade tende a vir como surpresa para aqueles estudiosos do teatro e da performance e para os praticantes que pensam o teatro como um lugar onde sistemas de valor e normas sociais estão invariavelmente em solo movediço, sujeitos a deslocamento e crítica devido à primazia do teatro sobre a ontologia e da máscara sobre a essência. Se estamos encenando ações socializadas no teatro, isso não significa que estamos declarando implicitamente que essas ações sejam "meras performances" e, portanto, modelos sociais que podem ser mudados? A teoria do teatro não é cheia de tentativas de desestabilizar o status quo?

As questões sobre a natureza subversiva do teatro e da performance recentemente culminaram em um debate entre teóricos da performance e teóricos da performatividade. Enquanto estudos da performance tendem a considerar a arte performática como subversiva, críticos como Judith Butler têm enfatizado que teatro e performance também produzem a normatividade social que eles podem pretender subverter em performances particulares. (BUTLER, 1993; BUTLER, 1990; MCKENZIE, 2001) Podemos, assim, nos voltar para a teoria da performatividade de Butler para explicar a normatividade inerente ao teatro. Todo ato de parodiar um ato roteirizado, normativo, é também uma repetição daquele ato normativo e portanto participa em formar, ao invés de abolir ou sobrepujar, a norma que o governa. Alienações teatrais de normas são dependentes e portanto envolvidas na produção de normas que podem procurar subverter. Em sua introdução a Bodies That Matter (1993), Butler deixa esta consequência de sua teoria explícita, insistindo que as performances teatrais são roteirizadas pelo comportamento normativo e por rituais públicos externos ao teatro. Até o ponto em que o teatro, mais do que qualquer outra forma de arte, replica o mundo social e em particular a interação humana através de humanos reais no palco, ele pode, portanto, ser considerado a forma de arte que está mais diretamente amarrado à normatividade social.

Outro modo de abordar a normatividade do teatro é analisar a maneira com que o drama de gabinete procura evitar representação teatral. O drama de gabinete cria um espaço que permite a Mallarmé defender que uma dançarina não é mais uma dança- 
rina, um espaço em que ele, o poeta masculino, pode assumir vários pseudônimos; essa é a condição que permite que Leopold Bloom se torne uma mulher (e isso significa se transformar real e verdadeiramente em uma mulher, ao invés de fazer apenas cross-dressing); e essa é a condição sob a qual nunca será possível reduzir Santa Teresa de Stein a qualquer forma, corpo ou personagem em particular. Neste ponto, podemos lembrar também que a história do drama de gabinete está, na verdade, cheia de várias formas de desvios, do Simpósio de Platão e da Medeia de Sêneca até a Tentation of Saint Anthony, passando por Cenci de Shelley, sem mencionar o texto que tem mostrado de uma vez por todas, e com todas as implicações possíveis e impossíveis, que o gabinete do drama de gabinete é também um boudoir: o drama de gabinete de Marquês de Sade, Philosophy in the Bedroom. Porque os dramas de gabinete usam sua liberdade da normatividade do teatro para criar mundos caracterizados por várias formas de ambiguidade e desvio, é possível adotar o projeto de Eve Kosofsky Sedgwick de uma epistemologia do gabinete para o drama de gabinete. (SEDGWICK, 1990)

A resistência à normatividade do teatro em ação nos dramas de gabinete fora dos padrões se torna claramente visível quando esse dramas de gabinete são trazidos de volta ao palco. Nas versões de palco de Livre, 'Circe' e Four Saints in Three Acts, a dançarina de Mallarmé se torna feminina mais uma vez; Leopold Bloom nunca se torna uma mulher; e Santa Teresa talvez nem mesmo flerte com Santo Inácio. Quando se contemplam estas mudanças, fica claro que o que preocupa Mallarmé, Stein e Joyce não é tanto uma simples retirada da esfera pública enquanto separação ou alienação da representação teatral plena, em particular do ator humano. A estrutura da resistência sugere que o drama de gabinete não consegue escapar inteiramente da normatividade teatral; que aquilo que se parece com liberdade do teatro nada mais é do que um efeito da resistência a ele. Isso é verdade, mas isso não significa que esses efeitos não sejam significativos. Isso significa que a resistência do drama de gabinete ao teatro também produz um teatro, um que rompe com a figura humana e se rebela contra os confinamentos miméticos de uma ação de palco e teatral. É no gesto da rebelião que o drama de gabinete ainda está calibrado com o teatro e deriva disso o material cuja decomposição é o processo através do qual constitui a si mesmo.

Os dramas de gabinete modernistas procuram desfazer o teatro e seus atores humanos através de programas que são mais bem descritos por termos como literariness, écriture ou writerliness. É importante reconhecer que, no contexto do drama de 
gabinete, estes termos não descrevem simplesmente a condição da literatura, mas, sim, representam uma escolha da literatura sobre o teatro. Da perspectiva do drama de gabinete, a valorização da literariedade pode ser entendida como uma reação contra a representação teatral. E exatamente como literaturnost e écriture são termos direcionados contra o teatro, da mesma forma a teatralidade é frequentemente direcionada contra o texto dramático, e assim sendo, à literatura em geral. (Evreinov, por exemplo, cunhou o termo teatralnost aproximadamente ao mesmo tempo em que Roman Jakobson cunhou o termo literaturnost.). Talvez o estudo do drama de gabinete seja um lugar privilegiado para se refletir sobre a relação conflituosa entre a cultura literária e o teatro. Reconhecer a relação essencial entre o teatro em ação nos dramas de gabinete de Mallarmé, Joyce e Stein, que alcançaram proeminência em outros gêneros literários, pode ser um bom caminho para introduzir a categoria do teatro, inclusive a resistência a ele, no estudo do modernismo literário em geral.

\section{Drama e Teatro Modernistas}

É apenas por meio do drama de gabinete e sua construção da plateia como leitor que podemos começar a compreender por que Beckett considera as indicações cênicas do teatro tão importantes quanto o diálogo, ou por que Brecht quer ensinar a plateia a adotar a postura de um leitor. Defendo que Yeats, Brecht, Beckett e de forma menos desenvolvida, o cânone todo do drama moderno adotam, do drama de gabinete, estratégias para incorporar o antiteatralismo não apenas na forma dramática, mas também na representação teatral.

Esta afirmação parece ser anti-intuitiva dado que estes três dramaturgos eram ativos no teatro. O uso da dança por Yeats, o teatro épico de Brecht, e as encenações meticulosas de Beckett indicam o fato de que ao invés de rejeitar o teatro como um todo, esses escritores tiveram um interesse agudo em assuntos teatrais. Embora isso seja certamente verdadeiro, eu mostro que Yeats, Brecht e Beckett estão engajados mesmo assim em um discurso explicitamente antiteatral em vários momentos de suas vidas: Yeats em sua fase mais tenra de escritor de peças simbolistas, Brecht em suas polêmicas contra Wagner, e Beckett em sua cruzada contra os atores. Mais importante, porém, do que suas denúncias por vezes categóricas ao teatro e à teatralidade (denúncias que ecoam ipsis litteris o antiteatralismo dos dramas de gabinete e dos teóricos modernistas antiteatrais) é o fato de que estas pessoas canalizaram sua resistência ao 
teatro de volta para dentro do próprio teatro. A explícita "desconfiança do teatro" de Brecht o leva a transformar atores em testemunhas, e a fantasia de controle inicial de Yeats de confinar atores em barris foi sagazmente posta em prática nos planos de Beckett de aprisionar atores em urnas, latas de lixo e montes de terra. O teatro de Yeats é tradicionalmente rotulado como simbolismo, assim como o drama político de Brecht e o teatro do absurdo de Beckett. A despeito destas diferenças, eles constituem três manifestações de uma compartilhada resistência modernista ao teatro. Na realidade, defendo que foi sua resistência ao teatro que provou ser a força motriz por trás das reformas e revoluções no teatro pelo qual eles são agora muito bem recohecidos.

Uma forma pela qual o antiteatralismo latente destes escritores e diretores está registrado é na objeção deles à política teatral propagada por Wagner e pelo teatralismo de vanguarda. Como Mallarmé e Joyce, Yeats e Brecht veem a afinidade entre a plateia e a esfera pública com a maior das suspeitas e procuram embutir em seus teatros políticos o maior número de elementos antiteatrais possível, com o mais importante sendo a limitação obsessiva da plateia. É por esta razão que a maioria das peças programáticas destes autores são peças de câmara, peças com uma profunda desconfiança quanto à plateia e uma política teatral. Os pequenos públicos vislumbrados por estes escritores são explicitamente não públicos, sua seleção é sempre questão de exclusividade, e mesmo seu comportamento é meticulosamente prescrito a fim de evitar que a coletividade desenvolva qualquer dinâmica própria, particularmente, qualquer coisa que lembre as revoltas tão intencional e estrategicamente provocadas pelos teatralistas de vanguarda.

A limitação e o controle da plateia são algo que o drama moderno aprendeu do drama de gabinete, que por sua vez sempre aceitou, como uma espécie de compromisso, uma pequena confraria assistindo uma leitura dramática ou mesmo uma encenação de câmara: o gabinete do drama de gabinete, em outras palavras, tanto pode ser um lugar para um público íntimo quanto para uma leitura solitária. O fato dos teatros pequenos serem a força motriz por trás da maioria das reformas da virada do século, assim sendo, não apenas reflete as pressões econômicas, mas também registra uma retirada deliberada de um público de massa para um espaço íntimo e privado. A tentativa de criar um antipúblico privado expurgado de tudo associado à teatralidade política é visível mesmo em Mallarmé, o mais radical dos dramaturgos de gabinete, que vislumbrou leituras perfeitamente programadas de suas peças por um grupo seleto de 
amigos, uma plateia íntima que lembra talvez aquela de um salão. Da mesma forma, alguns dramas de gabinete não rejeitam completamente, mas qualificam, a ideia do theatrum mundi, como fez Hofmannsthal, que reduziu o Great World Theater (1641) de Calderón a Das kleine Welttheater (O pequeno teatro mundo) (1897). É esta tentativa de criar um "pequeno" público, e portanto, ideal, que podemos ver funcionar em tais peça de câmara como "Peças para Dançarinos" de Yeats e Lerstücke de Brecht.

A persistência do antiteatralismo no drama modernista significa que, assim como o drama de gabinete, ele joga sua própria literariedade contra a teatralidade. Na realidade, é esta confiança no texto dramático como uma estratégia contra o teatro que registra mais claramente a afinidade entre o drama moderno e o drama de gabinete. Mais importante, entretanto, o drama moderno, mais do que qualquer drama anterior, se torna um gênero literário dirigido tanto para um leitor quanto para uma plateia. Neste ponto, meu projeto se intersecciona com a história do livro. Através de um longo processo, o qual Julie Stone Peters reconstruiu em The Theater of the Book, a cultura impressa e a performance tiveram uma história conflituosa e entrelaçada. O drama tem sido impresso desde antes do período elisabetano, e dramaturgos individuais tais como Ben Jonson devotaram considerável energia e notas explicativas às versões impressas de suas peças, que certas vezes eles preferiram no lugar de performances teatrais. No curso dos séculos XVIII e XIX, o drama contemporâneo (ao contrário da tragédia grega, de Shakespeare ou dos "clássicos") construiu gradualmente seu "leitor implícito", para usar o termo emprestado de Wolfgang Iser, não apenas como um profissional do teatro responsável por realizá-lo no palco, mas como um leitor genérico: todo texto dramático, portanto, é também, se não exclusivamente, uma leitura ou um drama de gabinete.

Um dos poucos observadores contemporâneos que reconhecem a importância da impressão para o drama moderno foi o crítico norte-americano Archibald Henderson, que atribuiu a crescente importância das edições impressas ao caráter internacional do drama moderno, que tem circulado na forma de traduções e antologias traduzidas, uma tendência ilustrada na singular influência das peças de Ibsen através da Europa. Este modo de publicação encorajou a prática da leitura do drama contemporâneo, uma prática fortalecida, anotou Henderson em 1914, pelo crescente estudo de literatura dramática em Harvard, Yale e Columbia. Causas adicionais que Henderson poderia ter somado à lista eram de natureza legal. A censura sempre foi mais restritiva em relação às performances teatrais do que com respeito a peças impressas, um desequilíbrio que 
já é ele mesmo o produto de um antiteatralismo enraizado e moralizante. E alterações nas leis de royalties nacionais e internacionais às vésperas do século XIX aboliram alguns dos desestímulos aos dramaturgos quanto a publicarem seus trabalhos antes de sua encenação. A integração do drama aos mercados de publicações genéricas, portanto, envolve um certo número de fatores práticos, legais e econômicos, através dos quais o drama fica aparentado, quando não co-extensivo, ao drama de gabinete.

Os dados quantitativos disponíveis sobre a publicação de peças são frequentemente insuficientes. $O$ que deixa a pesquisa quantitativa de impressão e publicação especialmente precária no caso do drama é o fato das peças serem frequentemente pirateadas por gerentes de teatro tentando evitar o pagamento de royalties ou impressas em edições baratas destinadas a atores e produtores. (STEPHENS, 1992) A falta de dados precisos marcando a evolução da prática da publicação de drama, porém, não tem tanta importância para o meu argumento, que está menos preocupado com as causas quantitativas do que com seus efeitos qualitativos sobre a forma genérica do cânone tão pequeno do drama moderno. Novamente, foi Henderson quem notou um particular efeito, nomeadamente, que não apenas fez Shaw gastar uma quantia extraordinária de tempo selecionando impressão, tipo e formato para a publicação de Plays Pleasant and Unpleasant, como o modo de publicação na verdade alterou a forma dramática: Shaw adicionou longos prefácios e passagens narrativas e assim mudou a forma e a função de suas direções de palco.O que Henderson observou em Shaw pode ser tomado como indicativo de que o drama moderno se realizou de modo mais geral como drama de leitura, primeiramente através da integração das rubricas no texto dramático primário. Esta mudança na função das indicações cênicas é uma consequência da história do drama impresso, e uma que só se manifestou plenamente no final do século XIX. As rubricas técnicas como a indicação de entradas e saídas, ou aquelas voltadas às descrições de personagens, seus posicionamentos e movimentos, não mais foram descrições direcionadas ao público genérico. As rubricas tornaram-se, portanto, um lugar privilegiado para a inovação formal. A emergência dentro do drama moderno de elaboradas indicações cênicas, descritivas e narrativas, revela uma postura mais geral de confiança por parte do drama moderno na linguagem que media, descreve, prescreve e interrompe o espaço mimético do teatro. Apontar para estas estratégias não significa tomar partido em uma luta sem fim entre texto e performance. Contudo, isso significa reconhecer, por um lado, que a performance 
teatral é parte do horizonte de qualquer texto dramático - mesmo o drama de gabinete se preocupa com a mimese do palco, na maioria das vezes de maneira negativa - e, por outro lado, que uma performance teatral muitas vezes insere mediações textuais entre o espectador e a mimese teatral. Proponho um termo para designar as estratégias descritivas e narrativas pelas quais o drama moderno procura canalizar, enquadrar, controlar e até mesmo interromper o que percebe como sendo uma teatralidade não mediada do palco e seus atores. Este termo é diegese.

\section{Mimese, Diegese e Gestos}

Diegese não é um termo neutro no debate entre texto e teatro, pois ele brota dos escritos antiteatrais de Platão, onde é usado em meio ao que pode ser encarado como a querela original entre a diegese verbal e a mimese teatral. No centro desta querela permanece a figura do ator. Platão chega à sua crítica do ator somente por um caminho indireto, através da rapsódia homérica, que narra a ação ocorrida no passado, no presente e no futuro, em um modo que Platão chama de "diêgêsis"

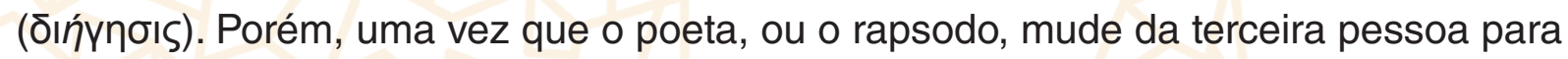
a primeira, ele não mais relata a fala de um personagem, mas "assemelha" (ó $\mu$ oIEIv) sua voz e seu gesto àqueles do personagem; o rapsodo não mais é um narrador, mas está a caminho de se tornar um ator. Neste momento, a diegese rapsódica dá lugar à mimese desempenhada por um ator. Para Platão, esta performance se tornaria,

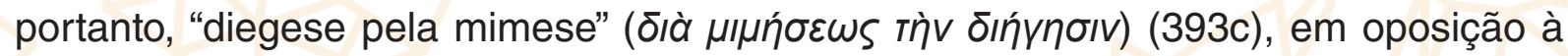
diegese pura ou simples, que seria definida por sua diferença em relação à mimese

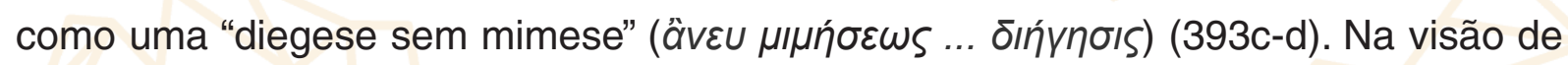
Platão, esta troca de rapsodo para ator é crucial porque significa que o poeta "esconde" (ámокрúттєıv) (393c) a si mesmo sob a máscara do personagem, uma máscara constituída de voz falsa e gestos falsos.

O diligente interlocutor deste diálogo - ou drama de gabinete - imediatamente reconhece que Sócrates não está realmente falando aqui sobre o rapsodo atuante, mas do ator dramático. É possível, em princípio, imaginar um poema épico sem nenhum discurso direto, e desta forma, um rapsodo que nunca tenta imitar a voz e os gestos de personagens, embora tal abstinente recitação nunca tenha ocorrido realmente, pois a recitação de poesia épica era um evento de palco que atraía grandes multidões. $A$ fim de demonstrar esta possibilidade, Platão oferece uma tradução para a terceira 
pessoa, e, portanto, para a diegese da fala de Crises no primeiro livro da llíada. Este tipo de tradução a princípio é possível para a poesia épica, mas poderia alterar tudo se fosse aplicada ao drama, pois o drama geralmente depende de atores falando com suas próprias vozes como meio de imitar as vozes dos personagens que estão personificando. Enquanto em teoria o rapsodo e a poesia épica poderiam ser salvos (se fossem apropriadamente transformados em narrativa pura sem diálogo), os atores e a forma dramática estão desesperadamente perdidos porque precisam imitar as vozes e os gestos de outras pessoas, especialmente, Platão declara, as vozes e gestos de mulheres e covardes (395a). Não surpreende, portanto, que quando fala sobre atores, Platão usa o termo grego padrão, nomeadamente, u்mokрírns, ou hypokrites, uma palavra cujo próprio significado foi reiteradamente imbuído pelo próprio antiteatralismo de Platão, até que tomou o sentido derrogatório que possui hoje.

A Poética de Aristóteles se apresenta como uma defesa da mimese contra Platão, usando conceitos tais como a catarse e o impulso humano em imitar. O que passa frequentemente despercebido, no entanto, é que Aristóteles também possui um sentimento ambivalente quanto à figura do ator. A maior concessão de Aristóteles a Platão é a afirmação de que o drama deveria ser capaz de ser feito inteiramente sem


vislumbra aqui uma leitura silenciosa. Mas Aristóteles, como sempre, tenta alcançar uma posição de compromisso, o que significa que ele também quer defender, pelo menos até certo ponto, os aspectos espetaculares e visuais do teatro (ö $\psi(\zeta)$. Para este propósito, ele destaca que todas as artes performáticas, incluindo rapsódia e música, para o bem ou para o mal, participam em algum modo de visualidade. Esta visualidade, como o autor, é bênção e maldição, e Aristóteles torna a narrar um exemplo negativo,

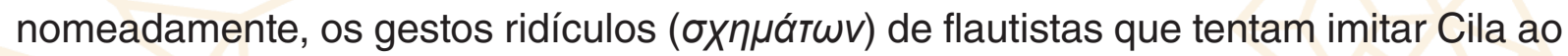
invés de suprimir essas influências externas em sua música (1461b) - Aristóteles soa aqui quase como Adorno. Este desejo por um compromisso se torna particularmente agudo quando se trata de atores, pois o desejo de Aristóteles de salvar os bons atores da crítica de Platão o leva a sintomáticas mudanças em sua terminologia. Frequentemente, ele foge do termo padrão de Platão para ator, nomeadamente hypocrites, usando em seu lugar a palavra пра́тtovтєS, ou prattontes, que é derivada da palavra praxis e, portanto, sugere a execução de uma ação real, em contraste ao enganador fingimento. A decisão de Aristóteles de usar praxis e prattontes para denotar uma ação 
apresentada por um texto dramático no palco pretende defender o teatro da acusação de que ele apresenta hipócritas que fingem emoções. E uma vez que Aristóteles tenha construído um agente-ator não hipócrita, ele pode prosseguir com a salvação da visu-

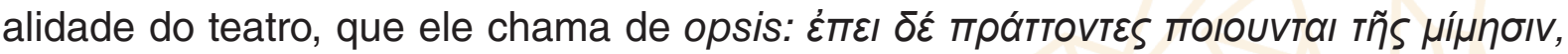

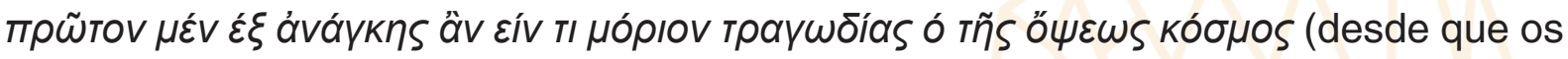
personagens/atores produzem mimese, segue-se que em primeiro lugar, a tragédia consistirá em espetáculo visual) (1449b30-32). A distinção entre hypocrites e prattontes espelha a diferença entre teatral e não teatral. Por um lado, palavras como atos, agentes, ações e atores denotam ações e suas consequências no mundo. Ao mesmo tempo, porém, esses conceitos também significam a representação de ação em um palco. Aristóteles reconhece ambos os sentidos e estrategicamente os funde usando a palavra praxis para denotar o ator teatral: agora o teatro deixa de fingir e, pelo contrário, se engaja em ações reais. Aristóteles dá ainda um passo adiante, transferindo a ênfase de atores para ações. Podemos imaginar tragédias sem personagens, diz Aristóteles, portanto, conclui-se, sem atores personificando-os (1450a24). Mas não seria possível existir tragédia sem ação ou práxis. Em última análise, então, Aristóteles pode salvar atores associando-os com a ação não enganosa, mas no final é a ação e não os atores, que ficam no centro da tragédia.

Por Aristóteles querer salvaguardar o bom ator, ele toma o cuidado de evitar o termo com o qual Platão conduziu seu ataque ao teatro: diegese. Esta evasão passa despercebida até mesmo por um narratologista tão rigoroso quanto Gérard Genette, que equivocadamente afirma que Aristóteles "aceita" a noção de diegese de Platão quando na verdade ele obviamente a evita. (GENETTE, 1994, p.128) Em vez disso, quando Aristóteles fala sobre narrativa, ele usa frequentemente termos alternativos,

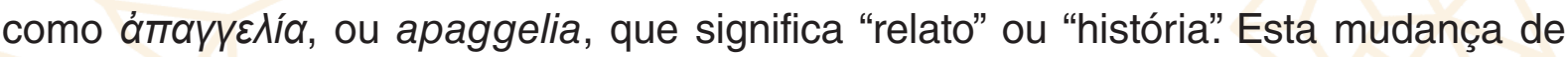
terminologia é estratégica porque está voltada para cercear a categórica oposição de Platão entre diegese e mimese, da mesma forma como o termo prattontes foi voltado para cercear o enganoso fingimento dos hypocrites. Em vez disso, Aristóteles espera categorizar a poesia épica, a poesia lírica coral e o drama como diferentes formas de mimese de tal forma que aquilo a que Platão se referiu como diegese sem mimese é agora uma sub-forma de mimese. $\mathrm{O}$ termo diegese, a arma antiteatral de Platão, foi assim efetivamente descarregada. 
A estratégia de Aristóteles para salvar e expandir a ideia de mimese e para suprimir o termo diegese de Platão tem sido tão bem sucedida que o termo diegese, com sua investida antiteatral implicada, foi completamente colocada de fora da análise do drama e do teatro e é usada apenas no estudo da narrativa. Deve-se certamente aplaudir a tentativa de Aristóteles de debelar a crítica de Platão aos atores e sua hipotética consequência: o fechamento dos teatros e o banimento dos atores. Mas esta simpatia pela causa de Aristóteles não deve nos impedir de usar o termo diegese, porque ele registra precisamente as forças antiteatrais em ação no drama e no teatro modernos. A fim de examinar estas forças, é necessário insistir com Platão e contra Aristóteles na distinção, e assim sendo, na luta entre diegese e mimese teatrais. Isso significa que devemos distinguir entre a representação indireta, descritiva e narrativa, de objetos, pessoas, espaços e eventos através da linguagem (falada por um rapsodo, narrador, coro, ou autor, ou representada no texto dramático pelo leitor) e a apresentação direta de tais objetos, pessoas, falas, espaços e eventos no palco. Apenas uma terminologia que reconheça essa distinção pode capturar as estratégias através das quais o drama e o teatro modernos tentam resistir à mimese teatral.

A tragédia e a comédia gregas, e na realidade o drama ocidental e não ocidental, sempre incluíram várias formas de diegese. Passagens narrativas sobre o passado podem ser contadas por atores, e comentários no tempo presente pelo coro. Ações ocorrendo fora do palco, por exemplo, são frequentemente relatadas por mensageiros ou por atores fingindo "vê-los do outro lado da parede" (teichoscopia). A função normal de tais formas de diegese no drama grego e no drama ocidental de maneira geral, é expandir o universo de representação para além do palco. Quando mensageiros relatam o que se passou em algum outro lugar, fora do palco ou por trás de uma parede, eles somam ao espaço mimético do palco o que Michael Issacharoff chama de espaço diegético de fora do palco. (ISSACHAROFF, 1989) Isso não é, porém, o sentido de diegese que está especificamente conectado com o drama moderno, embora seja a base para ele. Porque o drama moderno introduz uma mudança importante na função dessas estratégias diegéticas. Em vez de importar para o espaço mimético do palco algo que acontece fora dele, a diegese modernista se refere ao espaço mimético do próprio palco. (WORTHEN, 1992) Personagens, objetos e eventos que já estão presentes mimeticamente são subitamente confrontados com modos de diegese que projetam para o espaço mimético sua própria versão dele. 
O que está por trás desta tática de dirigir a diegese a favor e contra a mimese teatral é o desejo por parte do drama moderno de enquadrar, controlar e interromper o espaço teatral do palco. A representação teatral não é deixada para os designers, atores e o diretor, mas sim colocada uma vez mais nas mãos do autor dramático. No lugar de representação visual, tais como adereços, iluminação e a organização do espaço do palco, assim como o movimento, a coreografia e a atuação, temos agora a linguagem descritiva. A maioria das formas de diegese modernista, no entanto, não são o resultado de batalhas pelo poder entre diretores, atores e autores; como é característico do debate sobre teatralidade, esta postura antimimética se transforma em um ataque contra a teatralidade como tal. A diegese redefine o que vemos, e assim sendo, condiciona nossa percepção e recepção do teatro. Fazendo isso, ela media o teatro através de uma forma de arte muito mais aceitável ao modernismo, nomeadamente, a literatura. A diegese de Platão, sobre a qual toda essa energia antiteatral foi concentrada, é portanto retomada pelo drama moderno para o propósito de manter sob controle e mediar a mimese teatral de atores e objetos no palco. A estratégia de Aristóteles de recategorizar a diegese como uma forma de mimese pode ter salvo o teatro uma vez, mas não nos ajuda a compreender as relações sutis entre modernismo, antiteatralidade e texto dramático. Meu livro, portanto, examina o drama moderno pelas lentes do termo diegese de Platão, e nesse sentido, pode ser considerado não tanto um estudo do teatro não aristotélico, como Brecht o chamaria, quanto um teatro em débito com Platão. O drama e o teatro modernistas são um teatro platônico, não que seja um teatro de ideias abstratas, mas um teatro infundido com tipos de antiteatralidade desenvolvidos pela primeira vez nos dramas de gabinete de Platão. (GOULD, 1989)A fim de mapear todos os mecanismos diegéticos em ação no drama e no teatro modernos, é necessário distinguir entre diegese escrita e impressa (rubricas, falas descritivas e diegéticas no drama de gabinete) e diegese praticada (fala diegética falada pelo coro, comentaristas semelhantes ao coro ou personagens narrativos ou descritivos). Todas as indicações cênicas são descrições ou prescrições do espaço mimético no palco, mas tradicionalmente a duplicação inerente a esta projeção desaparece porque as direções de palco são consideradas apêndices técnicos dispensáveis que não aparecem no produto final, a performance. Mas quando o drama se realiza enquanto drama de leitura, suas direções de palco não mais desaparecem e dessa forma, repentinamente assumem novo significado; elas constituem uma narrativa ou 
discurso em terceira pessoa que assume o controle, para o leitor, do espaço mimético do palco. Enquanto alguns comentaristas, mais notavelmente Marvin Carlson, têm observado a ascensão e a mudança de significado das rubricas, poucos têm reconhecido neste fenômeno a mudança mais central que está ocorrendo no drama moderno. A crescente importância das rubricas alcançam um clímax nas indicações cênicas de Beckett, não porque sejam particularmente longas, pois a este respeito são superadas por aquelas de Shaw e O'Neill, mas porque elas envolvem um universo paralelo ao drama falado, e portanto competem com ele a todo momento. Ler as peças de Beckett requer uma leitura dupla da fala direta e das direções de palco, e dessa forma, suas peças são divididas entre um teatro de diálogo e um teatro de objetos e gestos, o último capturado pela diegese descritiva das direções de palco.

A diegese textual do drama moderno aparece de forma destilada no drama de gabinete moderno, cujas descrições de palco implícitas e explícitas conjuram um espaço teatral mimético apenas para desconstruí-lo completamente. Este pode ser - lugar para destacar que o drama de gabinete modernista não constitui um teatro "imaginário" no sentido em que o leitor deva simplesmente "imaginar" uma performance "visual" enquanto lê. Tal palco imaginário é produzido no ato da leitura de qualquer texto dramático tradicional; é o efeito de uma forma dramática que está voltada para o teatro. O drama de gabinete modernista, por contraste, não deixa o teatro intacto, nem mesmo na forma do teatro imaginário, mas procura interromper e desmembrar qualquer possibilidade de um palco real assim como de um palco imaginário. Neste sentido, o drama de gabinete moderno é uma instância do que Evlyn Gould chamou de "teatro virtual", mas ele também se volta contra esta tradição ao procurar desimaginar, desvisualizar, e destetatralizar o ato de leitura do drama.

O desmantelamento diegético até mesmo de um espaço teatral imaginário é a instância mais específica do modo mais geral com o qual o drama de gabinete moderno resiste ao palco. A função diegética das direções de palco e das falas descritivas emerge mais conspicuamente nas tentativas desajeitadas de se levar os dramas de gabinete para o palco, contra a força, por assim dizer, de suas mais antiteatrais estratégias diegéticas. Tais adaptações - do Livre de Mallarmé, do capítulo Circe de Joyce, da versão em libreto autorizada de Virgil Thomson para Four Saints in Three Acts de Stein - introduzem à força a figura de um narrador ou comentarista para acomodar as direções de palco diegéticas destes textos. Esses desajeitados narradores registram mesmo assim 
o fato de que as rubricas dos dramas de gabinete estão no coração do gênero, e não podem mais simplesmente desaparecer no processo de encenação.

Os narradores ou comentaristas que apresentam as rubricas diegéticas do drama de gabinete pertencem a uma classe mais ampla de personagens diegéticos que povoam o palco moderno. Derivados do coro grego ou do coro Nô, figuras diegéticas projetam falas que condicionam o espaço mimético que está simultaneamente presente aos olhos da plateia. As peças Nô de Yeats, por exemplo, usam um coro que não participa na ação da peça, mas ao invés disso, comenta na peça, mais particularmente, controla sua recepção através de falas descritivas, diegéticas. A diegese não é, contudo, sempre reduzida a algo como o coro, situado à margem do palco. Toda a reforma da atuação de Brecht pode ser vista como uma tentativa de transformar os atores em narradores diegéticos, falando como se estivessem relatando sua própria fala e condição. $O$ confronto aqui entre mimese e diegese acontece com cada um dos atores/personagens.

A função central de tais fenômenos aparentemente diversos como as indicações cênicas cada vez mais longas, o uso de um coro ou de figuras similares ao coro, comentaristas e finalmente atores que se tornam observadores de si mesmos, só podem ser compreendidos se reconhecermos que têm algo em comum: eles sobrepõem ao espaço mimético do palco camadas de descrição cujo propósito não é replicar o palco, como se para preservar sua característica particular teatral e mimética, mas para adapta-la, transformá-la e interrompê-la. É neste processo de adaptação ou transformação que podemos ver a marca de uma resistência produtiva ao teatro, uma resistência singular em sua motivação antiteatral, mas diversa em seus efeitos. O operador de Mallarmé, o narrador dramático de Joyce, as passagens descritivas e narrativas de Stein, o coro de Yeats, os atores épicos de Brecht e as rubricas de Beckett podem, assim, serem reunidos sob o termo diegese porque todas são direcionadas, no sentido de Platão, contra a presença não mediada da mimese teatral.

Mesmo que o termo diegese possa ser usado para descrever a resistência ao teatro, ainda assim ele contém aquilo a que resiste; indicações cênicas e narradores diegéticos não abandonam a mimese teatral, mas a enviam de volta para o literário, quer seja no texto ou na fala diegética. Isso significa que a diegese não apenas produz a filtragem do teatro pela literatura, como também cria, no processo, uma nova forma de teatro. Esta dinâmica se torna particularmente visível através do uso recorrente do termo gesto. Por diversas vezes, a maneira pela qual os escritores de drama de 
gabinete, assim como os dramaturgos modernos falam sobre seus textos, é através do gestual, da noção de Wagner da linguagem gestual e do flerte de Joyce com a teoria de gestos de Marcel Jousse, até a noção de Bracht de gestus. Baseando-se no duradouro debate sobre a origem gestual da linguagem e a esperança de que uma escavação de tal origem possa levar a um rejuvenescimento da linguagem literária, o particular investimento em escrita gestual indica o desejo da literatura pelo teatro. Essa tradição vai desde a análise de poesia em Language as Gesture de Richard Blackmur, ela mesma em débito com o chamado dramatismo de Kenneth Burke, até a noção de Derrida da écriture gestuelle de Mallarmé, uma tradição investida na teatralidade daquela literatura. Ao mesmo tempo, existe uma segunda tradição, que vai de Wagner e Artaud a Pavis, devotada a desenvolver teorias do gesto na esperança de criar especificamente sinais teatrais que ainda assim funcionassem como escrita. Ambas as tradições se baseiam em teorias da origem gestual da linguagem para estabilizar o termo gesto bem na fronteira entre literatura e teatro.

Gestos nunca são apenas texto ou escrita, eles infundem o texto com remanescências teatrais mesmo enquanto sugerem que uma performance teatral lembra a prática da significação no texto. Julia Kristeva chega perto de tal compreensão de gesto em seu estudo $\Sigma \eta \mu \varepsilon ı \omega t ı k \eta ~(1969)$ no qual ela descola o termo gesto de seu papel usual como origem da linguagem e utiliza-o para uma análise da produção de signos linguísticos inspirada no marxismo. (BLACKMUR, 1952) Gesto, aqui, se torna uma palavra para a práxis e o labor que se passam na produção da linguagem e da comunicação linguística, o labor que é mais ou menos apagado no produto finalizado linguístico. Uma análise do gestual em textos literários, então, se torna uma investigação dentro destas práxis ocultas, um domínio que para Kristeva é caracterizada por dois atributos: o impessoal e o espacial. Poderia-se adicionar um terceiro atributo, que ela não menciona talvez por causa de sua exclusiva atenção no estudo da novela, que é o teatral. Uma análise "gestual" do modernismo conduz diretamente à conflituosa relação entre texto e teatro, ou, para ser mais preciso, os respectivos valores colocados neles.

A análise do gestual revela, então, a face inferior da resistência, o fato de que o teatro, o drama de gabinete e o teatro antiteatral de maneira mais geral também produzem uma forma de teatro no interior de seu próprio ato de resistência. É esta cumplicidade entre rejeição e produção que está por trás das várias formas de drama moderno. Sua análise é o assunto de interesse deste livro. 


\section{Referências Bibliográficas}

ADORNO, T. W. Ästhetische Theorie. Frankfurt am Main: Suhrkamp, 1970. 1974.

Versuck das Endspiel zu verstehen. In Noten zur Literatur. Frankfurt am Main: Suhrkamp,

Philosophie der neuen Musik. 1949. Reprint, Frankfurt am Main: Suhrkamp, 1978.

ARISTOTLE. Poetics. Edited by Stephen Halliwell. Cambridge: Harvard University Press, 1995.

BENJAMIN, W. Illuminationen. 1955. Reprint, Frankfurt am Main: Suhrkamp, 1977.

BLACKMUR, R. P. Language as Gesture: Essays in Poetry. New York: Harcourt, Brace, 1952.

BUTLER, J. Bodies that Matter: On the Discursive Limits of "Sex". London: Routledge, 1993.

Gender Trouble: Feminism and the Subversion of Identity. London: Routledge, 1990.

DERRIDA, J. La dissémination. Paris: Éditions de Seuil, 1972.

FISCHER-LICHTE, E. The Show and Gaze of Theater: A European Perspective. lowa City: University of lowa Press, 1997.

FRIED, M. Absorption and Theatricality: Painting and Beholder in the Age of Diderot. Chicago: University of Chicago Press, 1980. 1998.

Art and Objecthood: Essays and Reviews. Chicago: University of Chicago Press,

FUCHS, E. The Death of Character: Perspectives on Theater after Modernism. Bloomington: Indiana University Press, 1996.

FUCHS, G. Die Schaubühne der Zukunft. Berlin: Schuster \& Loeffler, 1905.

GENETTE, G. Figures of Literary Discourse. Translated by Alan Sheridan. New York: Grove, 1994. GOULD, E. Virtual Theater from Diderot to Mallarmé. Baltimore: Johns Hopkins University Press, 1989.

HABERMAS, J. Strukturwandel der Öffent-lichkeit: Undersuchugen zu einer Kategoire der bürgerlichen Gesellschaft. 1962. Reprint, Frankfurt am Main: Suhrkamp, 1990.

HELLER, J. R. Coleridge, Lamb, Hazlitt, and the Reader of Drama. Columbia: University of Missouri Press, 1990.

HOFMMANSTHAL, H. Sämtliche Werke. Critical edition. 38 vols. Frankfurt am Main: Hochstift, 1982.

HUYSSEN, A. After the Great Divide: Modernism, Mass Culture, Postmodernism. Bloomington: Indiana University Press, 1986.

ISSACHAROFF, M. Discourse as Performance. Stanford: Stanford University Press. 1989.

LAWRENCE, D. H. Sea and Sardinia. 1921. Reprint, London: Olive Press, 1989.

LUKÀCS, G. Entwicklungsgeschichte des modernen Dramas. Vol. 15 of Georg Lukàcs Werke. 1911. Reprint, Darmstadt: Luchterhand, 1981.

MCKENZIE, J. Perform or Else: From Discipline to Performance. London: Routledge, 2001.

MARINETTI, F.T. Teoria e invenzione futurista. Milan: Arnoldo Mondadori, 1968.

NIETZSCHE, F. Richard Wagner in Bayreuth, Der Fall Wagner, Nietzsche contra Wagner. Sttutgar: Reclam, 1991.

PUCHNER, M. Stage Fright: Modernism, Anti-Theatricality \& Drama. Baltimore: Johns Hopkins University Press, 2002. 
RICHARDSON, A. A Mental Theater: Poetic Drama and Consciousness in the Romantic Age. University Park: Pennsylvania State University Press, 1988.

ROACH, J. R. The Player's Passion: Studies in the Science of Acting. Ann Arbor: University of Michigan Press, 1993.

ROUSSEAU, J-J. Lettre à M. d'Alembert sur son article Genève. Paris: Flammarion, 1967.

SCOLNICOV, H, and HOLLAND, P., eds. Reading Plays: Interpretation and Reception. Cambridge: Cambridge University Press, 1991.

SEDGWICK, E. K. Epistemology of the Closet. Berkeley: University of California Press, 1990.

SEGEL, H. B. Body Ascendant: Modernism and Physical Imperative. Baltimore: Johns Hopkins University Press, 1998.

SENNET, R. The Fall of Public Man. New York: Knopf, 1977.

SIMPSON, M. Closet Performances: Political Exhibition and Prohibition in the Dramas of Byron and Shelley. Stanford: Stanford University Press. 1998.

STEPHENS, J. R. The Profession of the Playwright: British Theatre, 1800-1900. Cambridge: Cambridge University Press, 1992.

VENDLER, H. H. Yeat's Vision and the Later Plays. Cambridge: Harvard University Press, 1963.

WAGNER, R. "Das Kunstwerk der Zufunkt”in Gesammelte Schriften und Dichtungen. 10 vols. Leipzig: Verlag von Fritzsch, 1871-73.

WILLIAMS, R. The Politics of Modernism: Against the New Conformists. Edited with an introduction by Tony Pinkney. London: Verso: 1989.

WINTERS, Y. The poetry of W. B. Yeats. Denver: A. Swallow, 1960.

WORTHEN, W. B. Modern Drama and the Rhetoric of the Theater. Berkeley: University of California Press, 1992. 